This is an open access article

under the CC-BY-SA license

\title{
IKEA in Indonesia: The Synergy of Swedish Public Diplomacy and Nation Branding
}

Anggia Valerisha*, Raden Fahrizal Ahadisuryo

anggia.valerisha@unpar.ac.id, fahrizal.ahadi@gmail.com

${ }^{12}$ Department of International Relations, Parahyangan Catholic University

\begin{abstract}
Public diplomacy and nation-branding are two popular concepts and closely related to diplomacy activities by both state and non-state actors. Szondi discusses the possible inter-connections of the two concepts and formulates understanding on how his concept can help to explain the various attempts of both state and non-state actors in achieving national interest. The unit analysis of this study is Sweden as state actor and IKEA as multi-national corporation. The existence of IKEA as company with its global-popular brand has becoming concerns for further research particularly on how IKEA brand as the instrument to supports Sweden's public diplomacy. This study aims to analyze Swedish public diplomacy and nation-branding in Indonesia through the IKEA brand as the case study and by using the model of public diplomacy and nation-branding proposed by Szondi. The study uses qualitative method with data collection carried out through documentation studies from 2014-2018. The findings indicate that the IKEA brand has unique characteristics. In Szondi's model, IKEA brand positioned in the incision between the area of public diplomacy activities and the area of nation-branding, which is described by Szondi as the fourth model. Through the IKEA brand, there is a synergy between Swedish public diplomacy activities and its nationbranding strategy. The IKEA brand has succeeded not only in the promotion of its products or companies, but also contributed to a positive image and reputation of Sweden and, increase social and economic engagement with Indonesia.
\end{abstract}

Keywords: IKE A, Indonesia, Nation-branding, Public diplomacy, Swedia.

\section{Introduction}

Public diplomacy has been an essential and important tool in international relations for the last decades (Cull, 2006). The strategy has been successfully used by The United States of America, ever since the mid of $19^{\text {th }}$ century. Various forms used as a government-sponsored programs intended to inform or influence public opinion in other countries, include mass media, films, video games, also student exchange and scholarship program (U.S. Department of State in Public Diplomacy Alumni Association, 1987).

Today public diplomacy is still relevant as nations' strategy in achieving its national interests and goals. The primary factor that has made public diplomacy so effective is because states are using the soft-power approaches. It uses the values, cultures of a nation, education, tourism, and economy as core aspects in conducting the strategy. Moreover, the effectiveness of public diplomacy finally seen by the acceptance of foreign public to the programs offered and could led to partnership between nations.

In its development, public diplomacy is often paired with 'nation-branding'. Both concepts occasionally used in the similar context, even 'nation-branding' sometimes is seen as part of public diplomacy. Nation-branding relates to how a nation carries out promotion or marketing technique to build a cohesive image for its people. This understanding has similarities with public diplomacy where the state, with various soft-power instruments, seeks not only to build the country's image or reputation but also to build public opinion while trying to formulate and execute

\footnotetext{
* Corresponding Author: Anggia Valerisha, Gedung 3 FISIP UNPAR, Jl. Ciumbuleuit 94, Bandung, Jawa Barat, 40141, Indonesia.
} 
its foreign policy. However, the concept of 'public diplomacy' and 'nation-branding' were born from two different fields of study (Szondi, 2008).

As a highly developed country, Sweden has a high-level gross domestic product (GDP). Its GDP grew by $2.3 \%$ in 2018 with a value of 551,135 million US dollar. The value has put Sweden in the $23^{\text {rd }}$ position globally with the highest GDP level out of a total of 196 countries in the world (Country Economy, 2019). This also positioned Sweden as one of the most advanced postindustrial societies (BBC News, 2018). Based on data in 2017, there were ten Swedish companies which are popular globally with the top ranks are occupied by IKEA, Volvo, H\&M, Ericsson, Skanska, Vattenfall, Electrolux, Scania, Securitas and Atlas Copco (Datantify, 2018)

The success of IKEA as a multinational company with its great brand image obviously has supporting Sweden to be a great nation-state. Interestingly, the IKEA brand has a visual image and company values that harmonize with Swedish national identity and national values. The fact that IKEA has hundreds stores in almost 50 countries globally, along with displays of Sweden's national colors which is blue and yellow, has making the statement of 'visiting IKEA means visiting Sweden' worth meaning (Olle Wastberg, 2009).

Based on the explanation, this study aims to analyze Swedish public diplomacy and nation-branding in Indonesia through the IKEA brand as the case study by using Szondi's approach and model of public diplomacy and nation-branding. The study intends to identify on how IKEA has supported its brand image as strategy of Swedish public diplomacy and nationbranding and how it is positioned in the construction of Szondi's approach and model.

In the traditional context of international relations, the activity to support nation-states to achieve their goals in various aspects and fields included to building an 'image' or 'reputation' is known as public diplomacy. The terminology of public diplomacy firstly introduced in 1960s by Edmund Gullion to explain the influence of public behavior in the formation and execution of foreign policy. It is summarized by the Murrow Center brochure where public diplomacy covers several dimensions such as international relations beyond traditional diplomacy, public opinion, interaction of groups and national interests between countries, the reporting of foreign affairs, communication between diplomats and foreign correspondents, and intercultural communication (Cull, 2006; Szondi, 2008).

Although public diplomacy has been an effective strategy, there has been changing in 1990s particularly related to the method used by state to manage their image or reputation. In many cases, aside from carrying out a more formal public diplomacy strategy, government uses public relations companies and applies brand management for their country, which was the domain of communication and business studies (Teslik, 2007). Thus, diplomacy has adopted the term 'branding' from business and communication studies and attached it to term 'nation'. This notion emphasizing state's interest in marketing its 'face' to public globally. In this context, the practice of 'nation-branding' that develops in public diplomacy emphasizes the existence of state's policy towards marketing or promotion efforts of a country through brands or branding.

Moreover, the study of 'nation branding' derived from Simon Anholt in 1996. He translated based on the observation that a country's reputation (or cities, or regions) behaves somewhat similar with corporate and product images (brand images), and are equally critical of progress, prosperity and good management of a country or region (Anholt, 1998, 2010, 2013). 
Western studies discussed on the term 'nation-branding' and tries to explore it from many perspectives and fields, such as international affairs, communications, and business-marketing. Gudjonsson (Cull \& Sadlier, 2009; Szondi, 2008) states that besides private actors, the government also played a certain role in the nation-branding process. In this case, the government or the private sectors uses power to influence anyone who can change the behavior, image, or identity of a country for the better reputation. The government can be the initiator or also have indirect involvement and influence. Fan (2010) emphasizes 'nation-branding' has a focus of attention on all matters relating to the state's image on the international stage in political and cultural but specifically in economic goals (Fan, 2010, p. 98). "The description of nation brand is a visual symbol... it can be easily branded and communicated. Each country has itself own unique name and image in the mind of people both inside and outside the country, so a nation does have brands" (Fan, 2010).

Other scholar, Kaneva (2011), discusses three perspectives of the assessment of 'nationbranding'. First, is the economic-technical perspective which see 'nation-branding' to develop and maintain a country's development strategy with the aim of economic growth. Second, is political perspective which regulates nation-branding as a powerful political tool to strengthen a country's economic position and to compete with economic, financial, or military forces, including the relations of superpowers. Third, the critical-cultural perspective when discussing the agreement on discourse and practices intended to rebuild the values and culture of nationality through marketing and brand paradigm (Kaneva, 2011).

The role of global companies or businesses in public diplomacy has been also discussed by businesses scholars. Goodman and Wang discuss that the global-scope businesses have act and recognize on their role as a bridge between nations. "The underlying premise is that business partners are far more likely to promote positive and productive global relationships that can in the long run lead to peaceful relations on a larger social and political scale" (Goodman, 2006).

Interestingly, Wang (2006) highlights that "public diplomacy is not a unitary but a multidimensional concept and argues for selective engagement by the private sector, that is not only desirable but also feasible... it also explains areas of public diplomacy that they may play a part in." (Wang, 2006). Aside from the role of businesses in public diplomacy, Indonesia's scholars have put more attention on how state actor is not a unitary actor in public diplomacy. Indonesia's scholars such as Effendi (2013), in his article he discusses the role of public diplomacy in strengthening Indonesia-Malaysia relationship. He concluded that state or government cannot work alone in public diplomacy and state can work together with other stakeholders to build a positive image and to spread good information for the public in order to build common understanding (Effendi, 2013). Meanwhile, Hennida's article argued about the importance of communication strategy, whereas the phase of dissemination of information, engagement dan influence had to be built both in the domestic and international level (Hennida, 2009).

\section{Szondi's Concept on Public Diplomacy and Nation-Branding}

The most basic yet simplistic concept about diplomacy is referred to the policy strategy of a nation to use communication activities - i.e. negotiation, persuasion, or promotion, to support the achievement of its national interests. Thus, public diplomacy under foreign affairs context means 'the activities of diplomacy through communication, which is done and initiated by the government or its representatives towards foreign public (i.e. promotion strategy and persuasion), to achieve its national interests' (Szondi, 2008). 
From different field of study of economic and business, the concept of 'nation-branding' is defined as 'promotional activities and the formation of the country's image through the actors or economic activities of the country concerned'. This concept of nation-branding itself strongly emphasizes as to 'form a positive perception of the domestic community regarding the image of the country' (Szondi, 2008). In its development, nation-branding activities are perceived the same as public diplomacy, yet this concept did not interfere with government activities. In nationbranding, private companies are the main actor, particularly in marketing brand products to build a certain image or reputation both to domestic and to foreign public.

\section{Traditional vs $21^{\text {st }}$ Century Public Diplomacy}

Szondi argues four dimensions in the traditional conceptualization of public diplomacy: 1) the conditions of the communication occurs between communicator and target country, 2) the purpose of communication, 3) power or 'the ability to shape the preferences of other people or countries', and 4) periodization of time of public diplomacy processes or activities. These dimensions are political-driven and draws into a more propaganda strategy rather than 'relationship-building'. In contrast, in the $21^{\text {st }}$ century, Szondi believes the practice of public diplomacy globally takes place when the world is at peace. The target or goal of public diplomacy in this century is to promote political and economic interests in shaping a receptive environment and building a positive reputation from a country abroad (or throughout the world). It is to build and to maintain a good relations with other countries, through various means (political and economic assets, and through old, new media, or personal media) and supported by a partnership between government and private sector, to attract the 'hearts and minds' of the people both domestic and abroad. Based on this understanding, Szondi emphasized that persuasion is not the main objective of public diplomacy, but is the 'relationship building'(Szondi, 2008).

\section{Models of Public Diplomacy and Nation Branding}

Szondi explained five possible models, between the concept of public diplomacy and nation-branding. First model illustrates the different processes of public diplomacy and nationbranding. Each concept goes their own way even though they are in a similar atmosphere. The difference lies in the communication strategy where nation-branding strategy is more directed (one-way) and its main purpose is to increase a country's awareness of a positive reputation and image, while public diplomacy uses two-way communication strategy to build cooperation and mutual understanding between the parties involved. Nation-branding emphasizes the special characteristics or the 'uniqueness' of a country, society, culture or landscape of a place. It is more transparent and accountable, compared to public diplomacy, which is smoother and slower in operation.

The second and third model of Szondi, show where one concept (process/practice/activity) is part of another process. In his second model, the practice of public diplomacy become part (or being participate) in the process/activity of 'nation-branding'. Here, nation-branding is the dominant channel in communication, and that is why the model uses a branding-approach in public diplomacy activities. In contrast, the third model, the practice or activity of nation-branding is part of public diplomacy activities. Nation-branding is an instrument of public diplomacy and emphasizes that brands are a channel to transmit national identity to consumers, which basically seems to have the effect of introducing a country of origin (COO) but 
in various dimensions both political, military, economic and socio-cultural. This conception was introduced in term of 'brand diplomacy' (Leonard et al., 2002) .

The fourth model implies different concepts for both public diplomacy and nationbranding, but when the activity is running, there are same elements found from the two concepts and both work well if synergized. Both concepts put 'nation' as unit of analysis, both has shared similar main elements, which are: how the image is formed, built, also about the culture, identity, and values. In addition, the key to this model also lies in the importance of 'relationship-building' which is supported by the 'communication network-approach', or communication activities that focus on exchanging messages and building relationships through networks. Thus, in this model, socio-cultural networking is an important element because it is truly relevant to the development of a relationship, especially in the context of relations between nations. The network, in this regard, is considered as a flexible and agile unit compared to the nation-state, so that the process of adaptation can occur more quickly than the expected changes in the international environment, as in the traditional sense of diplomacy.

Finally, the fifth model of Szondy illustrates both concepts are the same thing because of the identical characteristics they have, which is the promotional activity of a country with the main objective of forming a positive image.

Szondi also stated that the integration or linkages between public diplomacy and nationbranding can show different levels in each case. States can apply different models depending on the level of financial and human resources available, including its relation to the actual environment of the state and its government (Szondi, 2008).

\section{Methods}

This research is a qualitative research which case study is chosen to explain the phenomenon in specific context. Data is collected through primary documents such as diplomatic sources, company documents and catalogues, as well as secondary documents such as books, journals, web sites and news. The analysis was carried out through the specific concept and model framework of public diplomacy and nation-branding proposed by Szondi (2008).

The research subject in this study are both state and non-state actor. State actor in this regard are Sweden and Indonesia, meanwhile the non-state actor is shown through the IKEA as a private company or corporation. This study limits the data only from 2014 until the first quarter of 2019.

\section{Result and Discussion}

\section{The Swedish Model, Swedish politics, and IKEA}

Understanding the context is important to bring the comprehensive view towards the issue. Briefly, Sweden implements a 'public-private partnership', which is at the core of the Swedish Model of economy. It was developed by the Sweden's oldest party, the Social Democratic Party. This economic model has succeeded in creating an advanced welfare system and standard of living, along with the life expectancy of the Swedish people where the level is among the highest in the world (BBC News, 2018). Sweden also implements an open-economic policy that depends on exports. Its main exports are electronics, machinery, motor vehicles, communication equipment, computer products, as well as other products such as textiles, furniture wood, and household 
appliances and accessories (Kementerian Luar Negeri RI, 2019). Most Swedish products already have a global reputation because of their quality. The other brand and product, for example are Spotify and Fjallraven Kanken.

In a political context, Sweden has a neutral (non-alliance) political and defense policy strategy since 1945. The Social Democratic Party, which is a labor party, is the oldest party established in 1889. Since 2014, this party has governed together with the Green Party. Stefan Löfven, is the leader of this party who later who became the prime minister of Sweden from 2014 to the present. Basically, the policies adopted by this party are based on socio-cultural values such as freedom, equality, and solidarity. The party has prioritized its policies on creating jobs and providing better education for all (Sweden Government, 2019). Therefore, Sweden has an interest in low-politics issues and this also forms the basis of various Swedish public diplomacy projects in various parts of the world (Efe, 2017).

As the Swedish top brand, IKEA is a multinational company that holds huge coverage area globally. IKEA, founded in 1943, is a Swedish retail group that focuses its business activities in the field of designing and selling ready-made furniture and appliances or household furnishings. The brand is an acronym for the owner's name and background: Ingvar Kamprad (owner's name), Elmtaryd (the farm where he grew up), and Agunnaryd (a small village near Smaland which located in southern part of Sweden). Until 2018, IKEA has operations in 46 countries including in Indonesia. It has 375 stores spread throughout the world (52 stores in North America, 1 in Central America, 262 across Europe, 12 in the Middle East, 40 in Asia, and 8 shops in Australia). Meanwhile, until August 2016, IKEA has a sales turnover of up to 33.8 billion euros, with 172,000 partners worldwide, with a total catalog of 213 million printed in 32 languages include Indonesia (Bahasa). IKEA Indonesia established its first store in Tangerang in October 2014 (IKEA, 2019a, 2019b).

\section{IKEA Brand and the Image of Sweden}

It is somehow coincidence that the state and company brand are often interrelated. Commercial brand often introduced home countries and vice versa. Even at the same time, these corporate brands provide a more appealing to the country of origin (COO, just what has been happened to IKEA.

In 2009, Olle Wastberg, the Director General of the Swedish Institute (SI), a public body believed to disseminate knowledge about Sweden abroad (public diplomacy), stated that: "TKE $A$ has done more for Sweden's image than all the combined efforts of the government.". The statement is inseparable from the fact that IKEA operates in hundreds stores globally and the brand itself displays Sweden's national colors: blue and yellow. IKEA also serves Swedish traditional food and sells blonde wood designs and books about Sweden, making Sweden well-represented as a nation-state to people globally (Olle Wastberg, 2009).

Wastberg then suggested to improve Sweden's image, to give a clear, an exceptional position on Sweden internationally. Therefore, Swedish national bodies tried to identify and define Sweden based on associations made by the people around the world and what has been shown by IKEA brand. Through research, these bodies build a Swedish nation-branding platform with the placement of keywords. The main word is 'progressive', followed by 'innovative', 'open', 'caring', and 'authentic'. The keywords are represented the core values of Sweden (Olle Wastberg, 2009). 
An example, IKEA company is a pioneer in corporate social responsibility (CSR) activities, which emphasize the importance of a better working conditions and sustainability ('caring').

IKEA brand is dependent to the Swedish image and vice versa. Swedish textbooks published long before IKEA were founded, specifically related to design and innovation, showed that the international view regarding Sweden is 'simple and blonde'. The Stockholm exhibition in 1930 established the term 'functionalism' which is dominant in Swedish design and architecture. Sweden does have a design characteristic that emphasizes function over decoration. This view influenced IKEA brand to design their products, and later, it is known that IKEA produced the first blonde-woods home designs. Wastberg also states clearly: "Does Sweden use designs as a tool for nation branding today? Yes, the Swedish Institute continues to have exbibitions of Swedish design that travel the globe.”. Given that Sweden is a market-oriented country, Swedish companies continue to compete globally by adding value and knowledge to their products, which suits with the key words or core values: innovative, contemporary, but simple. It can be seen, Sweden uses design as a tool for its nation-branding globally and this is done through what has been offered by IKEA brand. Therefore, what has been shown between IKEA brand and the image of Sweden implies the benefits flow in both directions: Sweden benefits from the way IKEA markets its products, and IKEA also benefits from the Swedish image.

\section{The Role of Swedish National Bodies}

To support in achieving economic and social-political interests, Swedish government formed a special council that specifically handles matters related to the promotional of the state, which is called the Council for the Promotion of Sweden (Nämnden för Sverigefrämjande i Utlandet in Swedish and NSU for short). At first, it is consisted of five government-agencies: The Ministry of Foreign Affairs; Visit Sweden; the Ministry for Enterprise, Energy and Communications; the Swedish Trade and Investment Agency, and the Swedish Institute (SI). Latter is the most important institution dealing with public diplomacy in Sweden.

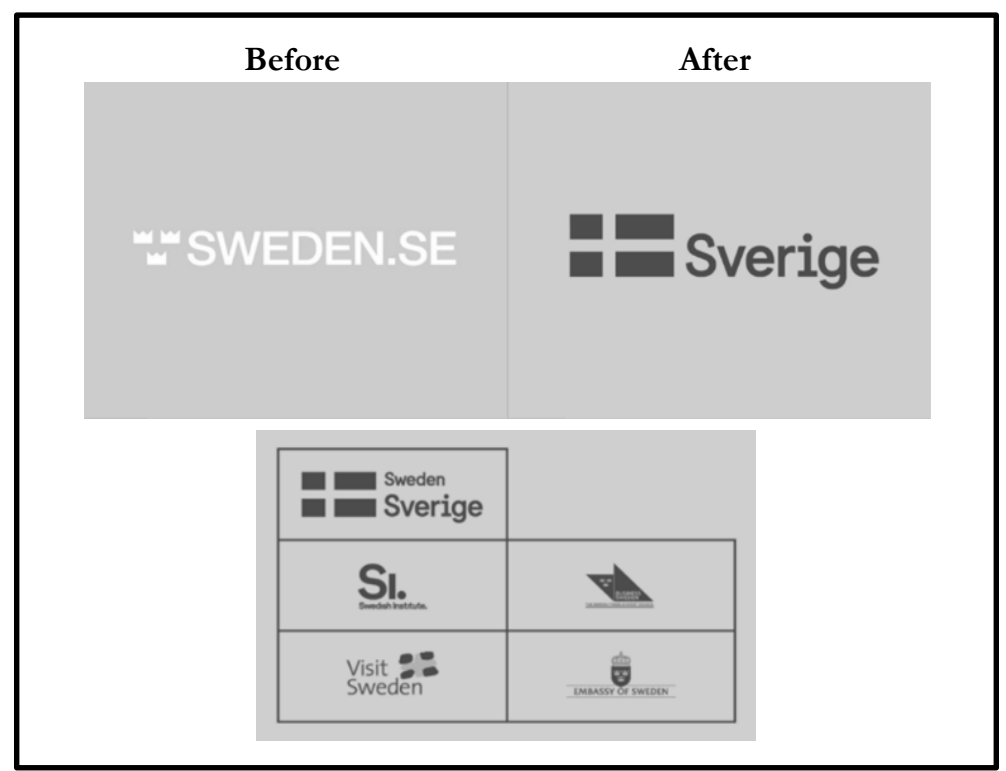

Figure 1. Sweden's Nation-Branding Logo Before and After Revision in 2017 
This is an open access article

under the CC-BY-SA license

The council was created in 1995 by the Swedish government with the aim of increasing effective and coordinated long-term promotion of Sweden's image abroad (Rosi, 2017; The Swedish Institute, 2019). In 2003, the NSU decided to study how Sweden perceived by other countries (Sweden Ministry for Foreign Affairs, 2005). Started in 2006, the council firstly introduced a brand design platform for Sweden. In 2007, NSU launched the brand-platform as a guide to promote Sweden internationally through various channels. This platform is not explicitly stated as a strategy, but as a communication platform that helps actors who use Swedish images as work objectives, such as embassies and business and investment (Rosi, 2017; The Swedish Institute, 2019).

Table 1. The Role of Members of the Council for the Promotion of Sweden (2017)

\begin{tabular}{|c|c|c|}
\hline $\begin{array}{c}\text { Member of the } \\
\text { Council }\end{array}$ & Commissioned by & Role \\
\hline $\begin{array}{l}\text { The Ministry for } \\
\text { Foreign Affairs }\end{array}$ & State, & $\begin{array}{l}\text { Responsible for Sweden's relations } \\
\text { with other countries and } \\
\text { international organisations, and for } \\
\text { development cooperation policy } \\
\text { and international trade policy. }\end{array}$ \\
\hline $\begin{array}{l}\text { The Ministry of } \\
\text { Enterprise and } \\
\text { Innovation }\end{array}$ & State/G & $\begin{array}{l}\text { Responsible for matters relating to } \\
\text { state-owned enterprises, enterprise } \\
\text { and industrial policy, rural affairs } \\
\text { and regional growth }\end{array}$ \\
\hline $\begin{array}{l}\text { The Ministry of } \\
\text { Culture }\end{array}$ & State/ & $\begin{array}{l}\text { Responsible for issues concerning } \\
\text { culture, democracy, media, the } \\
\text { national minorities, the language } \\
\text { and culture of Sami people, sport, } \\
\text { youth policy, civil society, faith } \\
\text { communities and burial and } \\
\text { cremation services. }\end{array}$ \\
\hline $\begin{array}{l}\text { The Swedish } \\
\text { Institute }\end{array}$ & State/Government & $\begin{array}{l}\text { A public agency that promotes } \\
\text { interest and trust in Sweden around } \\
\text { the world }\end{array}$ \\
\hline Business Sweden & $\begin{array}{l}\text { State/Government } \\
\text { and the Swedish } \\
\text { industry }\end{array}$ & $\begin{array}{l}\text { To help Swedish companies grow } \\
\text { global sales and international } \\
\text { companies invest and expand in } \\
\text { Sweden }\end{array}$ \\
\hline Visit Sweden & $\begin{array}{l}\text { State/Government } \\
\text { and the Swedish } \\
\text { tourism industry } \\
\text { (50/50 private-public } \\
\text { ownership) }\end{array}$ & $\begin{array}{l}\text { To promote Sweden as a tourist } \\
\text { destination abroad and has offices } \\
\text { in } 12 \text { countries }\end{array}$ \\
\hline
\end{tabular}

In 2009, the SI, as the important institution dealing with Swedish public diplomacy, stated that the IKEA's network of companies needed to use place-branding as a marketing tool. However, the lack of cohesiveness between Sweden country promotion logo and IKEA logo has made it difficult to be done. Thus, in 2013, the NSU introduced a new logo and identity designed 
by Stockholm-based Söderhavet to help the five agencies communicate cohesively to represent Sweden along with the Sweden-based company's logo and brand. The second revised edition published in 2017, both titled "Sweden Sverige" presented in Figure 1.

This platform is Sweden's strategy to increase global knowledge about Sweden, so that it can attract investors, talented people, tourists, and political alliances. On the same year, in 2017, the NSU board member was expanded to involve the Swedish Ministry of Culture and Business Sweden, which is a merger of the Swedish trade council and investment agency with business sector. The role of each institution can be seen in Table 1 .

\section{Sweden-Indonesia relations}

Since the first technology company, Ericsson, entered Indonesia in 1970s, more than 80 Swedish businesses have followed Ericsson's footsteps to open branches in Indonesia. For years, Indonesian companies used products and technology owned by Sweden. Indonesia is also perceived as one of countries with the largest economy in the world in the next few years (Business Sweden, 2019). In 2017, Johanna Brismar Skoog, the Swedish representative for the Swedish embassy in Indonesia showed Sweden's interest in further strengthening bilateral relations between Sweden and Indonesia. In May 2017, King Carl Gustaf XVI visited Indonesia to attend a forum of Indonesian-Sweden Executive Business Forum (ISEF) and was attended by 35 business delegations from Sweden. It was initiates to explore Indonesia's economic potentials while also strengthening political, economic, and cultural relations in the long term. The forum was attended by Swedish companies such as Volvo, IKEA, H\&M, Oriflame, and other companies (Hapsoro, 2019; Speirs, 2017).

Besides attending ISEF as the main agenda, King Gustav XVI and His wife Queen Silvia attended several small forums which were focused on the Swedish-Indonesian bilateral relations in the implementation of Swedish foreign policy. One of them was a seminar on the state forests in Indonesia, which was initiated by the International Center for Forestry Research (CIFOR) which is a non-profit organization that is engaged in the field of forestry to implement SDGs. It is one of Sweden's focus that to be implemented by Sweden in several countries that have bilateral cooperation with Sweden (Perrson, 2017). After the visit, both parties, Sweden and Indonesia signed another Memorandum of Understanding $(\mathrm{MoU})$ to strengthen bilateral relations between Indonesia-Sweden (Antara News, 2017):

(President Joko Widodo) “Sweden is Indonesia's largest trade partner in the Nordic. Swedish investment figures increased by more 1,400 percent in 2016 compared to $2015 \ldots$ The number of tourists coming to Indonesia from Nordic countries also continued to increase up to 15 percent...I welcome the signing of three agreements on providing visa-free facility for diplomatic and official passport holders; transportation, including air navigation and airports; as well as creative industries, innovation, entrepreneurship, science park and education funding...Sweden and Indonesia have similarities in the field of foreign policy. Both played an active role in the UN Peacekeeping force and supported for Palestinian independence. Sweden and Indonesia also prioritized peaceful resolution of conflicts with constructive efforts, so that these assets could be capitalized" (Antara News, 2017).

According to Skoog, the relationship between Indonesia and Sweden is more than just bilateral cooperation and trade relations, but it is also an intimate relations in implementing agendas or dealing with international issues such as security issues, peacekeeping agendas and the implementation of SDGs which is the agenda of the UN (Speirs, 2017). 


\section{Swedish Diplomacy in Indonesia through IKEA: Public Diplomacy or Nation Branding?}

As a country within the profile of 'liberal' and 'peaceful', Sweden has the primary interest of building long-term relationships with other countries, and this relationship should be able to encourage the fabrication and development of cooperation and trade (Sweden Government, 2019). The Swedish government realized that the use of soft power will be far more effective than hard power. For this reason, Swedish government uses public diplomacy and nation-branding activities. Various efforts were made by the government to create long-term relations with other countries, such as information-sharing, knowledge-sharing, developing skills, promoting cultural exchange and cooperation, also providing funds and grants. They were also supporting and collaborating with various actors, such as businesses, universities, cultural institutions and, of course, the Swedish embassies throughout the world (The Swedish Institute, 2019).

IKEA uses Swedish culture as part of its marketing strategy including in Indonesia. The company tells the story of Sweden which is recognized and identified by both Swedish and nonSwedish. The fact that IKEA translated the story into 32 languages included in Bahasa, has shown its commitment to attract foreign people to trust in Sweden. Kamprad's story was told on the official Swedish website to promote the country's image internationally. IKEA eventually became the symbol of what political scientist, Benedict Anderson, called the 'imaginaries community', referring to the state as a collective social construction located in certain history and geography. Kamprad is also seen as a heroic entrepreneur who overcomes obstacles posed by the market through the value of hard work. The theme of hard work supports aspects of the DIY concept designed by IKEA. The fact that the government promotes these values in the market shows how strong Sweden's export its country's values to the global audience include to Indonesia people.

The success factors of Sweden and IKEA are also supported by the storytelling of Kamprad in building his IKEA business. In this case, the historical significance of the personal background and the brand are determinant factors in the realization of Swedish values. This process has been categorized as 'nation-branding' according to Szondi.

In comparison, Swedish public diplomacy is an activity of the Swedish government to introduce Sweden to foreign people and it is conducted in dialogue-based (two ways communication). In the case of Swedish public diplomacy in Indonesia, Sweden held the European Higher Education Fair Expo every year. This activity is effectively invited people who want to continue their tertiary education in Sweden. Another example was Wiki Gap which were held in Yogyakarta (March 2018), Padang (September 2018) and Bandung (March 2019) as part of the International Women's Day celebration. In a collaboration with the Flower Aceh Foundation, for example, the Swedish embassy carries out the Swedish Dads photo exhibition in Banda Aceh (October 2018) and in Timor Leste (November 2018). The activity was also filled with public discussion with the theme of gender equality policies, both from the perspective of law and religion. Other Swedish public diplomacy includes public discussions with universities, film screening, international film festival that were held in various cities in Indonesia (Ahadisuryo, 2018).

In the context of Sweden-Indonesia relations, it is found that Swedish public diplomacy in Indonesia is based on peaceful and good relations between the two parties. The purpose of Swedish public diplomacy is to achieve political and economic interests to create a receptive 
environment and a positive reputation abroad. The strategy of Swedish public diplomacy is to build and maintain relations with other countries and involve the public in the process. The communication process in Swedish public diplomacy is carried out in two directions (dialoguebased) as it can be seen in several activities conducted by the Swedish embassy in Indonesia. The context of the message relates to ideas, values, and collaboration. Interestingly, IKEA brand has pointed out this message effectively rather than what has been done the Swedish embassy. Indonesian people as the main audience in this context has shown their interests and positive response towards IKEA brand. The involvement of the Swedish government is considered supportive and controlling over the brand especially when the IKEA brand has the predeterminant historic values related to Sweden.

From the explanation above, it can be said that both public diplomacy and nationbranding in the case of IKEA, are two different activities happened in the same atmosphere. Each activity has their own characteristics, especially on how the communication process is delivered to the people. It is argued that in the IKEA case, promotional activities are supported by both government and the businesses, as it has been shown by the role of the Council for the Promotion of Sweden (NSU). Even IKEA brand can be said as the inspiration for the Sweden revised country logo in 2016. Swedish public diplomacy and nation-branding, both are dependent in the case of Indonesia. As has been stated, the characteristics of nation-branding is one direction communication and it has been done by IKEA advertisement and IKEA brand concept. Meanwhile, the characteristics of public diplomacy is two-ways communication that upholds dialogue with the foreign people, in this case Indonesia's people. Public diplomacy is carried out by the Swedish government especially the Ministry of Foreign Affairs (i.e embassies), while nationbranding is carried out the collaboration between government and industry, which is IKEA and it is one-direction of communication. In Szondi's model based on Figure 2, IKEA brand positioned in the incision between the area of public diplomacy activities and the area of nation-branding, which is described by Szondi as the fourth model.

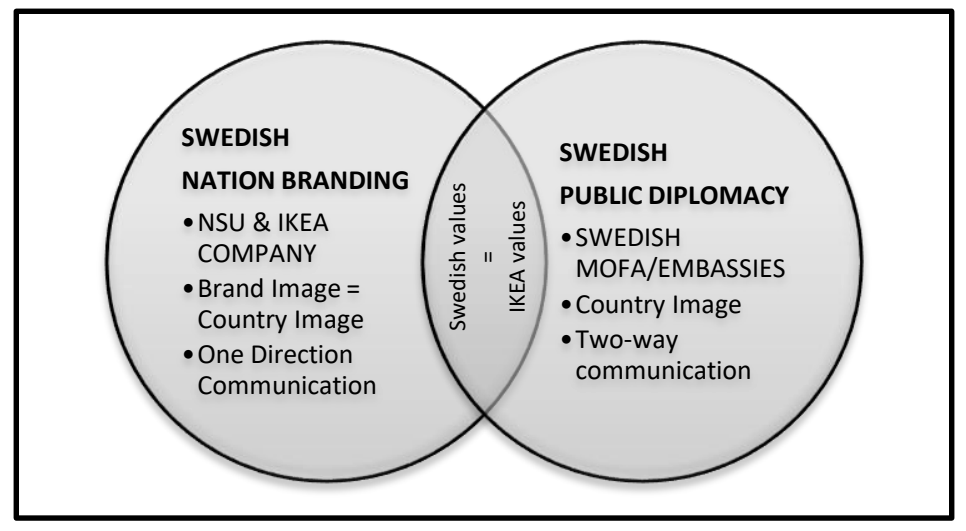

Figure 2. Swedish - IKEA Model of Public Diplomacy and Nation Branding

The model characterized by different process, but when it runs, there are the same elements, such as ideas, cultural, and values of the nation, that fits and shows mutualism with the brand. Thus, it can be said there is a synergy between public diplomacy and Swedish nationbranding through IKEA. The case shows the technical economic determination, and it is because the IKEA brand is powerful enough to boost economic, politic, and social engagement or 
development in the countries where they have invested, include Indonesia. In addition, the IKEA brand has shared the same culture, same identity, and IKEA holds strong values of relationship building as what has been desired by Sweden. However, the Swedish government, especially through The Council also holds as an important position.

\section{Conclusion}

The strategy of public diplomacy and nation-branding through IKEA has successfully reinforcing Sweden's national goals to strengthen international relations and development in many aspects and fields. Although both strategies have the same purpose, which is to promote Sweden, there are specific characteristics of each activity. In the case of IKEA brand in Indonesia context, Swedish public diplomacy and its nation-branding are two different activities, however, both have shown the mutualism in terms of values they had. The IKEA brand has the same values with Sweden, and it has affected positively to Swedish image and reputation. Moreover, Swedish model of public diplomacy and nation branding in Indonesia in the case of IKEA is categorized as Szondi's fourth model. The IKEA brand has succeeded not only in the promotion of its products and brand, but also contributed to a positive image and reputation of Sweden and, increase economic, political, and social engagement with Indonesia. To conclude, the synergy between public diplomacy and nation-branding has benefited both Sweden and IKEA as a brand. Meantime, further research is still needed to support the findings particularly with quantitative method, such as through survey to gain feedback from Indonesian people about their perception of Swedish and IKEA.

\section{References}

Ahadisuryo, R. F. (2018). Upaya Nation Branding Swedia oleh IKE A di Indonesia [Parahyangan Catholic University]. https://doi.org/http://hdl.handle.net/123456789/8402

Anholt, S. (1998). Nation-Brands of the Twenty-First Century. Journal of Brand Management, 5(1), 395-406. https://www.semanticscholar.org/paper/Nation-brands-of-the-twenty-firstcentury-Anholt/b484bc436f3ec3caa6e2745fb6ef0e7b6ea66655

Anholt, S. (2010). Places: Identity, Image and Reputation. Palgrave Macmillan.

Anholt, S. (2013). Beyond the Nation Brand: The Role of Image and Identity in International Relations. Exchange: The Journal of Public DIplomacy, 2(1), 6-12. https://surface.syr.edu/exchange/vol2/iss1/1

Antara News. (2017). Indonesia, Sweden Sign Three Agreements. https://en.antaranews.com/news/111036/indonesia-sweden-sign-three-agreements

BBC News. (2018). Sweden Country Profile. BBC. https://www.bbc.com/news/world-europe17955808

Business Sweden. (2019). Business Sweden. http://business-sweden.se

Country Economy. (2019). Sweden Profile. www.countryeconomy.com

Cull, N. J. (2006). "Public Diplomacy” Before Gullion: The Evolution of a Phrase. USC Centre on Public Diplomacy.https://www.uscpublicdiplomacy.org/blog/public-diplomacy-gullionevolution-phrase

Cull, N. J., \& Sadlier, D. J. (Darlene J. (2009). Public Diplomacy : Lessons from the Past (N. J. Cull (ed.)). 
This is an open access article

under the CC-BY-SA license

Figueroa Press.

Datantify. (2018). Swedish Global Brands. www.datantify.com

Efe, S. (2017). Public Diplomacy and The Implementation of Foreign Policy in the US, Sweden and Turkey.

Palgrave Macmillan. https://doi.org/10.1007/978-3-319-49334-3

Effendi, T. D. (2013). Diplomasi Publik sebagai Pendukung Hubungan Indonesia-Malaysia. Jurnal Ilmiah Hubungan Internasional, 9(1), 46-61.

Fan, Y. (2010). Branding the nation: Towards a better understanding. Journal of Place Branding and Public Diplomacy, 6, 97-103. https://doi.org/10.1057/pb.2010.16

Goodman, M. B. (2006). The Role of Business in Public Diplomacy. Journal of Business Strategy, 27(3), 5-7. https://doi.org/10.1108/02756660610663763

Hapsoro, B. (2019). Furthering Indonesia-Sweden Good Relations (Opinion). The Jakarta Post.

Hennida, C. (2009). Diplomasi Publik dalam Politik Luar Negeri. Jumal Masyarakat, Kebudayaan Dan Politik, XXII(1), 17-23.

IKEA. (2019a). About Us: IKEA. www.ikea.com

IKEA. (2019b). IKEA Indonesia. www.ikea.co.id

Kaneva, N. (2011). Nation Branding: Toward an Agenda for Critical Research. International Journal of Communication, 5(0), 25.

Kementerian Luar Negeri RI. (2019). Indonesia-Sweden. www.kemlu.go.id

Leonard, M., Stead, C., Smewing, C., \& Foreign Policy Centre (London, E. (2002). Public Diplomacy. Foreign Policy Centre. http://www.fpc.org.uk

Nye, J. S. (2004). Soft Power: The Means to Success in World Politics.

Olle Wastberg. (2009). The Brand Symbiosis of Sweden and IKEA. https://nationbranding.info/2009/07/08/brand-symbiosis-sweden-ikea/

Perrson, J. (2017). Sweden and Indonesia Signs Defence MoU. Scandasia. https://scandasia.com/sweden-and-indonesia-signs-defence-mou/

Rosi, A. (2017). Swedish Nation Branding in Crisis: A study on the Swedish Nation Branding Strategy and the Migration Crisis' Impact. Uppsala Universiteit.

Speirs, A. (2017). An Interview with H.E. Johanna Brismar-Skoog. Now Jakarta. https://nowjakarta.co.id/people/now-people/an-interview-with-h-e-johanna-brismarskoog-ambassador-of-sweden-to-indonesia

Sweden Government. (2019). Sweden Government. https://www.government.se

Sweden Ministry for Foreign Affairs. (2005). Images of Sweden Abroad - A Study of the Changes, The Present Situation and Assessment Methods. www.imagebank.sweden.se

Szondi, G. (2008). Public Diplomacy and Nation Branding: Conceptual Similarities and Differences.

Teslik, L. H. (2007). Nation Branding Explained. Council of Foreign Relations. https://www.cfr.org/backgrounder/nation-branding-explained

The Swedish Institute. (2019). The Swedish Institute. https://www.si.se

U.S. Department of State in Public Diplomacy Alumni Association. (1987). Dictionary of International Relations Terms; What is Public Diplomacy? http:/ /www.publicdiplomacy.org/1.htm

Wang, J. (2006). Public Diplomacy and Global Business. Journal of Business Strategy, 27(3), 41-49. https://doi.org/10.1108/02756660610663826 